\title{
Application of qPCR Method for Investigation of Plant Colonization by Human Pathogen Bacteria
}

\author{
Kljujev Igor
}

\begin{abstract}
The consumption of vegetables is very important for prevention cardiovascular diseases and it is recommended by WHO. The fresh vegetables are essential for healthy nutrition and provide minerals and vitamins. The vegetables are mostly consumed raw and it is very important to avoid its microbiological contamination during the production chain. The disease which are caused by human pathogen bacteria are very big problem for public health. These bacteria are able to contaminate fresh vegetables in any part of chain of food production.

The Salmonellosis is the usual foodborne infection which is caused by bacteria Salmonella spp. According to U.S. Public Health Service (2009), Salmonella is in the second place as causer of foodborne disease in the USA. Approximately, there are 40000 cases of Salmonellosis in the USA per year (DFBMD 2009).

The most common serovars which are found worldwide are Salmonella enteritidis and Salmonella typhimurium but others serovars are limited to specific regions in the world (OIE 2005).
\end{abstract}

How to cite this book chapter:

Igor, K. 2019. Application of qPCR Method for Investigation of Plant Colonization by

Human Pathogen Bacteria. In: Vucelić Radović, B., Lazić, D. and Nikšić, M. (eds.)

Application of Molecular Methods and Raman Microscopy/Spectroscopy in Agricultural Sciences and Food Technology, Pp. 45-57. London: Ubiquity Press.

DOI: https://doi.org/10.5334/bbj.d. License: CC-BY 4.0 
Today, there is lot of methods for detection human pathogen bacteria in food. The conventional methods are generally timeconsuming. The PCR is much faster and with qPCR we can get results only in few hours. The PCR allows increasing speed, sensitivity, specificity of detection of human pathogen bacteria in fresh vegetables.

The aim of this study is application of the qPCR method for detection of Salmonella enterica subsp. Welteweden and Salmonella typhimurium LT2 in wheat seedlings.

Bacterial strains used in this experiment were Salmonella enterica subsp. Welteweden and Salmonella typhimurium LT2. The model plant was wheat. The bacterial suspension applied for inoculation seeds was $\approx 10^{8} \mathrm{CFU}$. The inoculated plants left to grow in phitochamber for 3 weeks. The standard PCR was done for Salmonella strains. The primers for Salmonella were: rfbJ; fliC; fijB; invA, hilA. It was done cloning for getting plasmid with invA gene which was used for preparing standards for qPCR. Isolation Salmonella DNA from plants was done using kit. The sequencing of invA isolated from plant samples also was done.

The qPCR was done for DNA samples isolated from wheat root, shoot and substrate liquid inoculated with Salmonella strains. The Fluorescence In Situ Hybridization was done for inoculated plant samples. It was used specific probes for detection Salmonella by CLSM.

The results show that both investigated Salmonella strains were able to colonize wheat plants. The number of Salmonella DNA copies was $4.01 \times 10^{6}$ per $1 \mathrm{~g}$ root (S. enterica) and $3.32 \times 10^{7}$ per $1 \mathrm{~g}$ root (S. typhimurium).

\section{Introduction}

In recent years, there is an increasing number of outbreaks caused by consumption fresh vegetables which are contaminated with human pathogen bacteria. The application organic fertilizers and contaminated irrigation water are the main reasons of contamination by pathogen bacteria during the food production.

The consumption of vegetables is very important for prevention cardiovascular diseases and it is recommended by World Health Organization. The fresh vegetables are essential for healthy nutrition and provide minerals and vitamins. The vegetables are mostly consumed raw and it is very important to avoid its microbiological contamination during the production chain.

Recently there has been an increasing number of outbreaks caused by contaminated fresh vegetables. According to CDC (Center of Disease Control and Prevention, 2010), the lettuce was the one of the most frequent source of foodborne outbreaks in USA during the 2007.

Today, there are many methods for detecting human pathogen bacteria in food. The conventional methods which are based on cultures are generally timeconsuming and new methods are needed to exceed their performance. 
Immunology-based methods for detection human pathogen are very powerful tools and they provide extraction pathogen from bacterial suspension usingantibody coated magnetic beads. The PCR methods give more conclusive results, especially recent advances in PCR technology.Thus, with Real-Time-PCR (RT PCR), we are able to get very precise results only in few hours. Today, the most common methods for human pathogen detection in fresh vegetables are: colony counting technique, PCR and immunology-based methods. The PCR is much faster than other techniques and it takes approximately 6 to 24 hours to get result and this method does not need and include any previous enrichment steps. On the other hand, with RT PCR we can get results faster, only in few hours.

The general (conventional) PCR protocol for detection human pathogen bacteria in samples includes: denaturation of DNA, annealing of sequence specific primers, extension by polymerase $25-40$ cycles. The PCR product can be analysed by gel electrophoresis or DNA sequencing. The qPCR is technique for amplification and simultaneously quantification a targeted DNA molecule.The qPCR allows detection and quantification of DNA sequence in real time after amplification cycle. The quantification includes fluorescent dyes which insert with double-stranded DNA during PCR oligonucleotide probes that illuminate after hybridization with complementary DNA and extension. The qPCR is combination of the amplification DNA and quantification of amplified DNA in real time. Also, it is possible to use probes which are labeled with different dyes and they allow quantification and detection of multiple target genes in one PCR reaction.

In comparing with conventional microbiology methods, the PCR technique is much faster and requires less time to achieve precise and valid results. The advantage of PCR is detection of bacteria which are not able to grown in culture. The PCR allows increasing speed, sensitivity, specificity of detection human pathogen bacteria in fresh and ready to eat vegetables.

Today, it is known two qPCR methods, TaqMan and SYBR Green. The TaqMan PCR is based on fluorescent probes which must be selected according to very strict conditions and it cannot be always applied. The SYBR Green qPCR provides fast result compared to others technique and detection is based on binding of SYBR-Green dye into double stranded PCR products. It could be applied without the needing for probes linked to fluorescent molecules.

This study tries to develop protocol for rapid and precise detection of human pathogen bacteria in contaminated plants using the qPCR. The aim of this work is to develop and improve microbiological laboratory analysis of human pathogens using real-time PCR, develop a PCR method and develop a validation of protocol for it. It is very important to establish simple and reliable qPCR method which is using SYBR Green that could be suitable for routine analyses of Salmonella spp. in plants and fresh vegetables.

In general, the aim is application of the real time qPCR method for detection ofSalmonella enterica subsp. Welteweden and Salmonella typhimurium LT2 in wheat seedlings and to get an expertise with pathogen detection methods using real time qPCR techniques. 


\section{Materials, Methods and Notes}

Bacterial strains which are used were Salmonella enterica subsp. Welteweden and Salmonella typhimurium LT2. The model plant for inoculation was wheat. The sterile wheat seed was incubated on NB plates at $30^{\circ} \mathrm{C}$ for 3 days, letting them germinate and plants were grown on quartz sand in sterile conditions. The bacterial suspension which is applied for inoculation seeds was $\approx 10^{8} \mathrm{CFU}$ $\left(\mathrm{OD}_{600}=0.7\right)$ for both Salmonella strains. Before inoculation, the seedlings were washed in sterile $\mathrm{H}_{2} \mathrm{O}$ five (5) times and they were kept in bacterial (Salmonella) solution 1 hour at $20^{\circ} \mathrm{C}$ before planting. The inoculated plants left to grow in phytochamber for 3 weeks.

The standard PCR was done for pure culture of Salmonella enterica subsp. Welteweden and Salmonella typhimurium LT2. The standard PCR included extraction bacterial (Salmonella) DNA using the Genomic DNA From Tissue kit, NucleoSpin Tussue (Machery-Nagel, www.mn-net.com). It was used specific primers for Salmonella: rfbJ; fliC; fijB; invA and hilA (for Salmonella typhimurium LT2). It was used $16 \mathrm{~S}$ PCR Program: Hotstart at $94^{\circ} \mathrm{C}-5 \mathrm{~min}$.; Denaturating at $94^{\circ} \mathrm{C}-45 \mathrm{sec}$.; Annealing at $54^{\circ} \mathrm{C}-45 \mathrm{sec}$.; Elongation at $72^{\circ} \mathrm{C}$ - $45 \mathrm{sec}$.; Final elongation at $72^{\circ} \mathrm{C}-5 \mathrm{~min}$.; Store at $4^{\circ} \mathrm{C}$ - continous ( 30 cycles). The electrophoresis was done in $1 \%$ Agarose in TAE Buffer $+3 \mu \mathrm{EtBr} / 100 \mathrm{ml}$ at $120 \mathrm{~V} ; 400 \mathrm{~mA} ; 100 \mathrm{~W} ; 45$ minutes.

Also, FISH (Fluorescence In Situ Hybridization) was done for pure cultures of Salmonella enterica subsp. Welteweden and Salmonella typhimurium LT2. The cultures of Salmonella strains incubated overnight in NB Broth at $37^{\circ} \mathrm{C}$ with shaking. After that, it was done fixation in Paraformaldehyde (PFA) (for $\mathrm{G}^{-}$bacteria) according to Protocol Fixation Of Bacterial Liquid Cultures. The
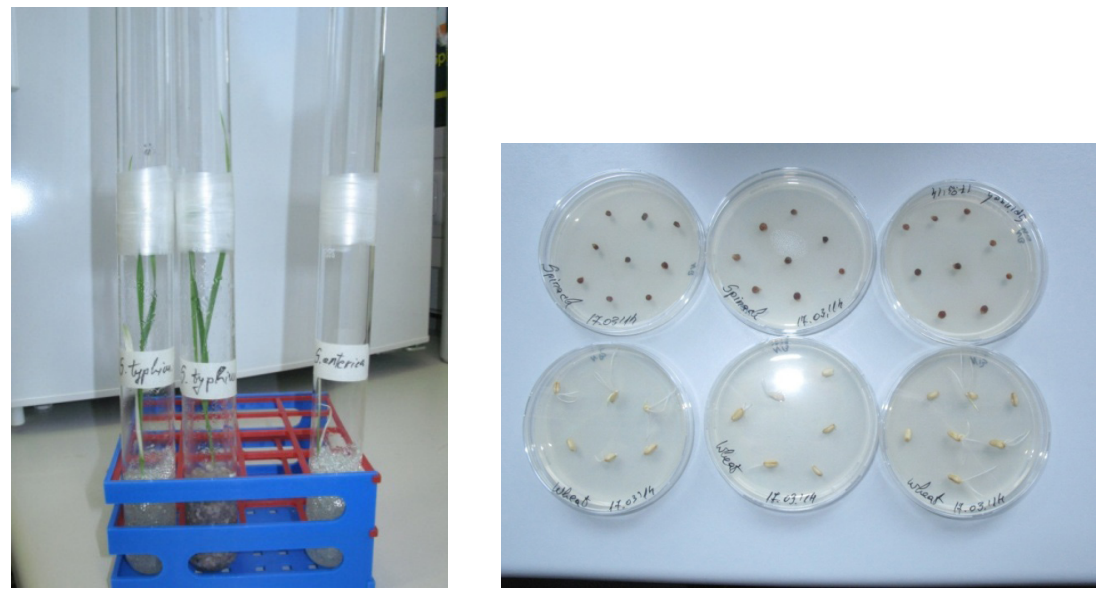

Figure 1: The wheat plant in glass tubes and seed germination in Petri dish. 


\begin{tabular}{|c|c|c|c|c|c|}
\hline Primer & $\begin{array}{c}\text { Target } \\
\text { gene }\end{array}$ & $\begin{array}{c}\text { Primer } \\
\text { length } \\
(\mathrm{bp})\end{array}$ & Sequence & $\begin{array}{c}\text { Size of } \\
\text { amplified } \\
\text { fragment } \\
\text { (bp) }\end{array}$ & $\begin{array}{c}\text { Numbers } \\
\text { designate } \\
\text { Genbank- } \\
\text { EMBL-DDBL } \\
\text { ID numbers } \\
\text { of the } \\
\text { sequences in } \\
\text { databases }\end{array}$ \\
\hline $\begin{array}{l}\text { RfbJ-s } \\
\text { RfbJ-as }\end{array}$ & $r f b J$ & $\begin{array}{l}24 \\
24\end{array}$ & $\begin{array}{l}\text { 5'-CCAGCACCAGTTCCAACTTGATAC-3' } \\
\text { 5'-GGCTTCCGGCTTTATTGTTAAGCA-3' }\end{array}$ & 663 & AE008792 \\
\hline $\begin{array}{l}\text { FliC-s } \\
\text { FliC-as }\end{array}$ & fliC & $\begin{array}{l}24 \\
24\end{array}$ & $\begin{array}{l}\text { 5'-ATAGCCATCTTTACCAGTTCCCCC-3' } \\
\text { 5'-GCTGCAACTGTTACAGGATATGCC-3' }\end{array}$ & 183 & D13689 \\
\hline $\begin{array}{l}\text { FljB-s } \\
\text { FljB-as }\end{array}$ & $\mathrm{fljB}$ & $\begin{array}{l}24 \\
24\end{array}$ & $\begin{array}{l}\text { 5'-ACGAATGGTACGGTCTCTGTAACC-3' } \\
\text { 5'-TACCGTCGATAGTAACGACTTCGG-3' }\end{array}$ & 526 & AF045151 \\
\hline $\begin{array}{l}139-\mathrm{s} \\
141-\mathrm{as}\end{array}$ & $\operatorname{inv} A$ & $\begin{array}{l}26 \\
22\end{array}$ & $\begin{array}{l}\text { 5'-GTGAAATTATCGCCACGTTCGGGCAA-3' } \\
\text { 5'-TCATCGCACCGTCAAAGGAACC-3' }\end{array}$ & 284 & $\begin{array}{l}\text { Malorny at al. } \\
(2003)\end{array}$ \\
\hline
\end{tabular}

Table 1: Primers for Salmonella strains.

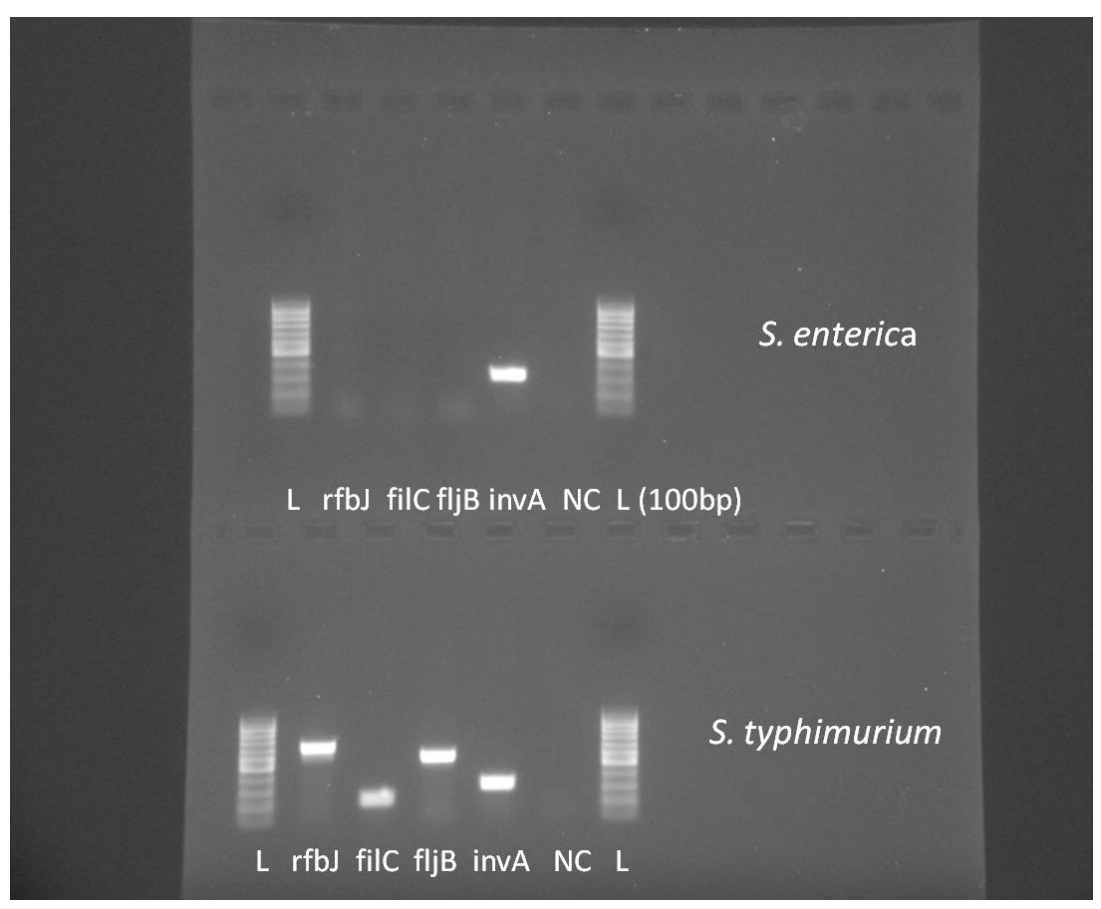

Figure 2: Standard PCR for pure culture of Salmonella. 
oligonucleotide probes used in this analyze were: Salm-63-Cy3; Gam42a-Fluos; Bet42a-Oligo. The FISH protocol is: add 1-10 $\mu$ l PFA-fixed sample onto glass slide; drying at $46^{\circ} \mathrm{C}$; EtOH-dehydration in $50 \%, 80 \%, 100 \%$ for $3 \mathrm{~min}$. each; air drying; add $8 \mu \mathrm{l}$ hybridization buffer and $1 \mu \mathrm{l}$ probe. The samples were observed by CLSM (confocal laser scanning microscope).
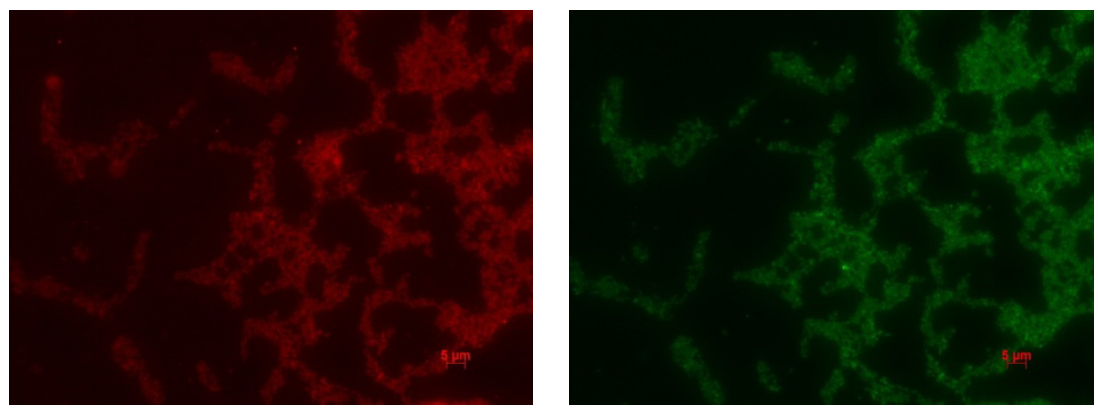

Figure 3: FISH for pure culture of Salmonella typhimurium LT2.

qPCR Analyses: In the goal to preparing standards for qPCR, cloning was done to get plasmid of Salmonella strains. PCR cloning was done for invA gene at Salmonella strains (Salmonella enterica subsp. Welteweden and Salmonella typhimurium LT2) according to PCR cloning protocol StrataClone PCR Clonong Kit (Stratagene). The protocol includes: Isolation plasmid with invA from E. coli competent cells (it is done by kit Plasmid DNA purification according to protocol NucleoSpin Plasmid QuickPure protocol); preparing standards for qPCR (it is calculated a number of moleculs per $1 \mu \mathrm{l}$ of invA copies). After that, qPCR for DNA samples of Salmonella pure cultures was done according to 16 $\mathrm{S}$ PCR program and qPCR-samples were run on the gel.
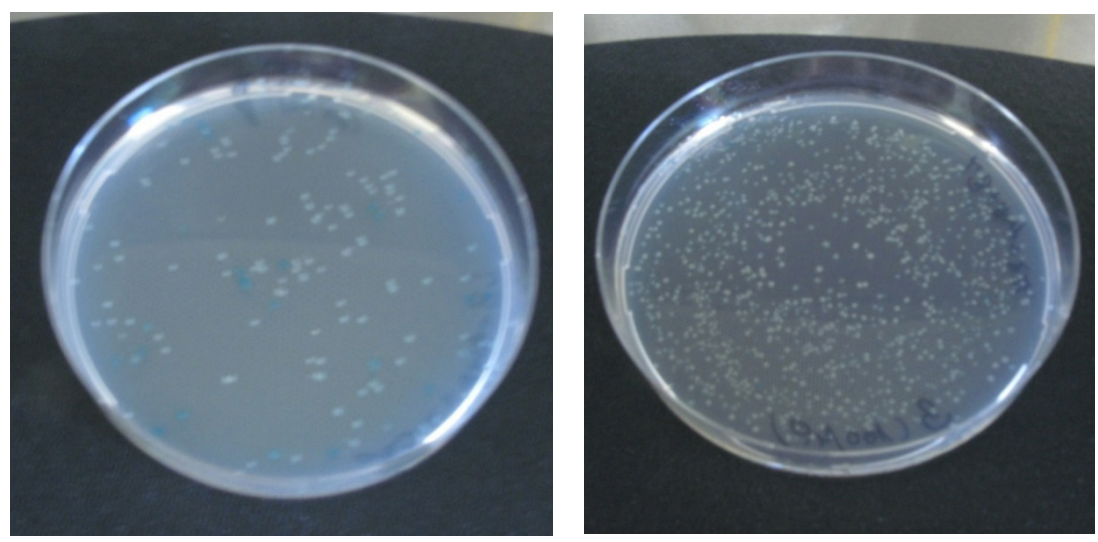

Figure 4: Colonies of transformed competent cells with plasmid of invA. 
Isolation of Salmonella DNA from plants: The Salmonella DNA was isolated from:wheat root; wheat shoot (stem and leaves) (quartz sand) liquid. The protocol for isolation Salmonella DNA from wheat plants and substrate liquid includes: it is taken $0.5 \mathrm{~g}$ of plant material and $500 \mu \mathrm{l}$ of liquid for analyses; the plant root and shoot were crashed with mortar and pestle in liquid nitrogen; after that, DNA from plant material and substrate liquid are further isolated according to FastDNA SPIN Kit for Soil (www.mpbio.com). Standard PCR for DNA isolated from plant and liquid samples was done to check presence of Salmonella DNA. The positive control is DNA isolated from Salmonella pure culture and negative control is reaction mixture without DNA.

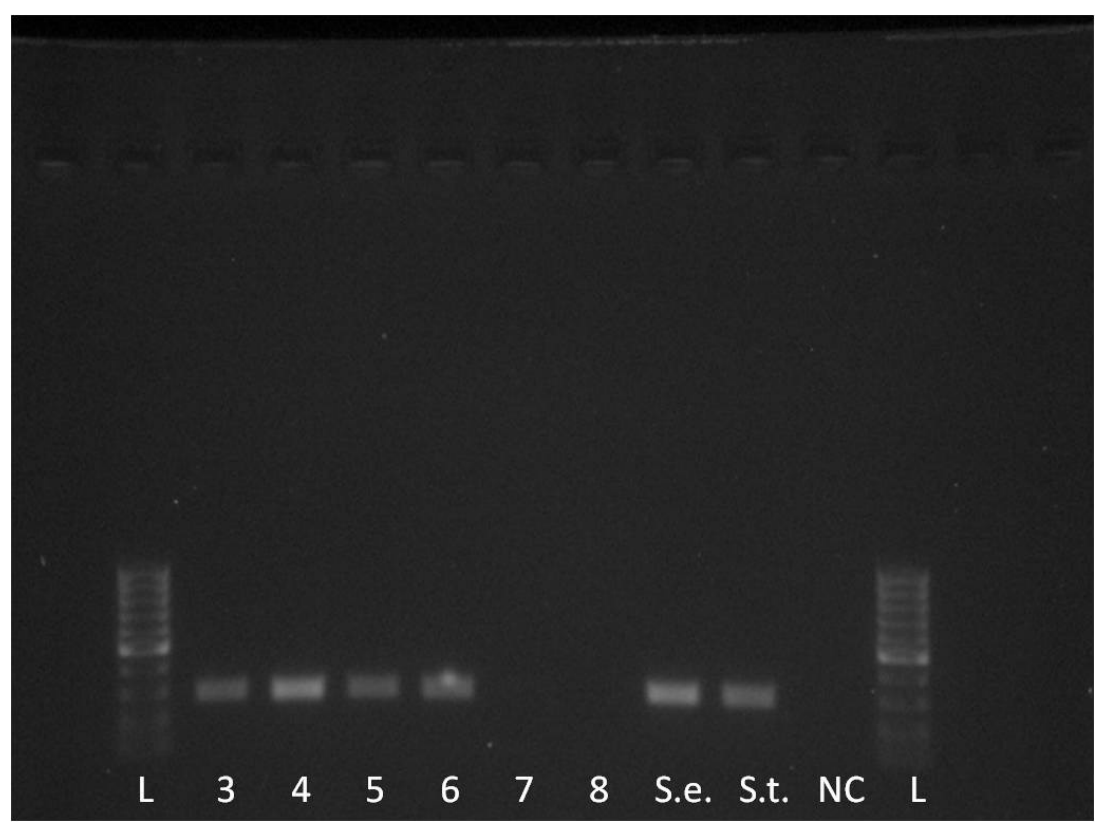

Figure 5: The standard PCR for DNA isolated from plant samples to check presence of Salmonella DNA (invA).

Legend: 3-wheat root inoculated by Salmonella typhimurium LT2; 4-wheat shoot inoculated by S. typhimurium LT2; 5-wheat root inoculated by Salmonellaenterica subsp. Welteweden; 6-wheat shoot inoculated by S.enterica subsp. Welteweden; 7-substrate liquid inoculated by S. typhimurium LT2; 8-substrate liquid inoculated by S.enterica subsp. Welteweden; S.e. and S.t.-positive control; NC-negative control.

Also, sequencing of invA isolated from plant samples was done and this analysis consisted of thefollowing: standard PCR; run gel; purification PCR mastermix samples; determination of DNA concentration by NanoDrop; Seq-PCR; 
purification Seq-PCR product; putting samples in microtiter plate and doing sequencing.

Finally, the quantitative PCR (qPCR) was done for DNA samples isolated from: wheat root inoculated with Salmonella typhimurium LT2; wheat shoot inoculated with Salmonella typhimurium LT2; wheat root inoculated with Salmonella enterica subsp. Welteweden; wheat shoot inoculated with Salmonella enterica subsp. Welteweden; liquid inoculated with Salmonella typhimurium LT2 and liquid inoculated with Salmonella enterica subsp. Welteweden. The DNA samples were run on the gel.

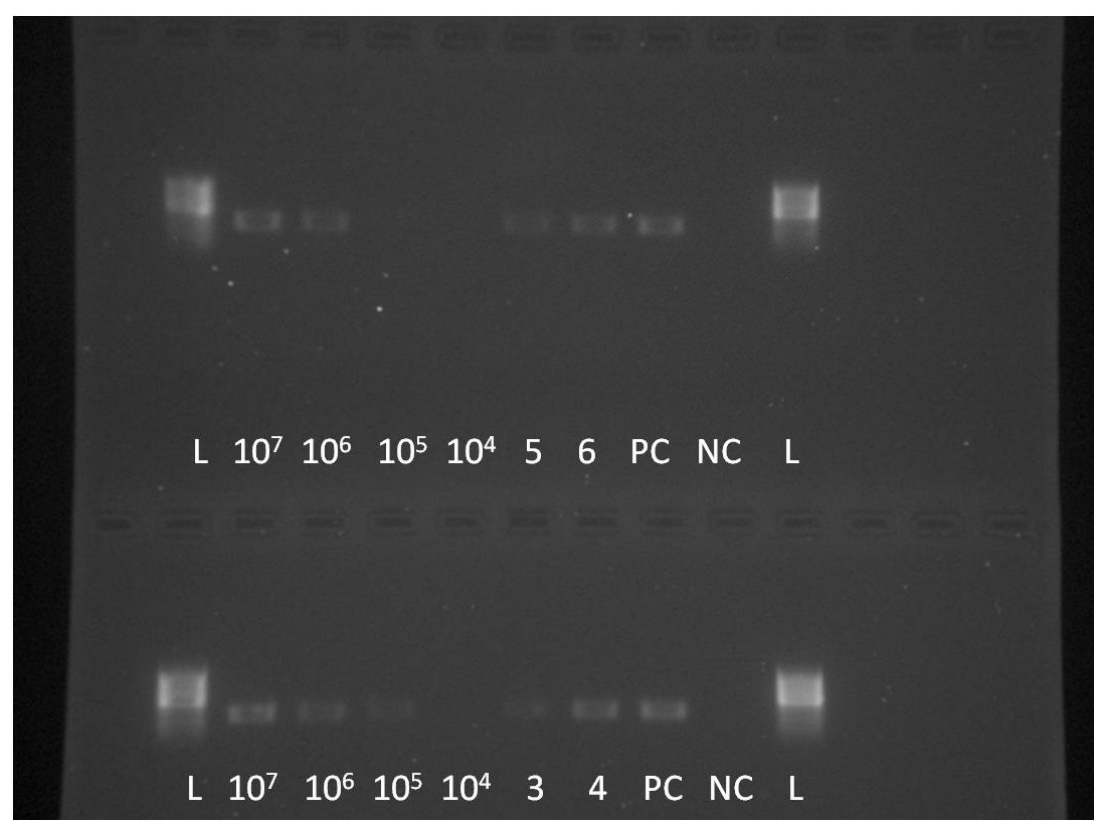

Figure 6: qPCR products of wheat samples inoculated with Salmonella strains $(3 ; 4 ; 5 ; 6)$ on the gel.

Legend: 3-wheat root inoculated by Salmonella typhimurium LT2; 4-wheat shoot inoculated by $S$. typhimurium LT2; 5-wheat root inoculated by Salmonellaenterica subsp. Welteweden; 6-wheat shoot inoculated by S.enterica subsp. Welteweden; PC-positive control; NC-negative control.

Also, FISH was done for inoculated plant samples and CLSM analyses and sampleswere: wheat root, stem and leaf. The specific probes which were used for detection Salmonella strains by CLSM were: Salm 63 - Cy3 (red); Gam 42 Fluos (green) and Bet 42 a - Oligo. The FISH analyses were done according to protocol: In Situ Hybridization Protocol for plant material. 
The investigated Salmonella strains were able to colonize wheat plants. The number of Salmonella DNA copies was $4.01 \times 10^{6}$ per $1 \mathrm{~g}$ root $(S$. enterica) and $3.32 \times 10^{7}$ per $1 \mathrm{~g}$ root (S. typhimurium).

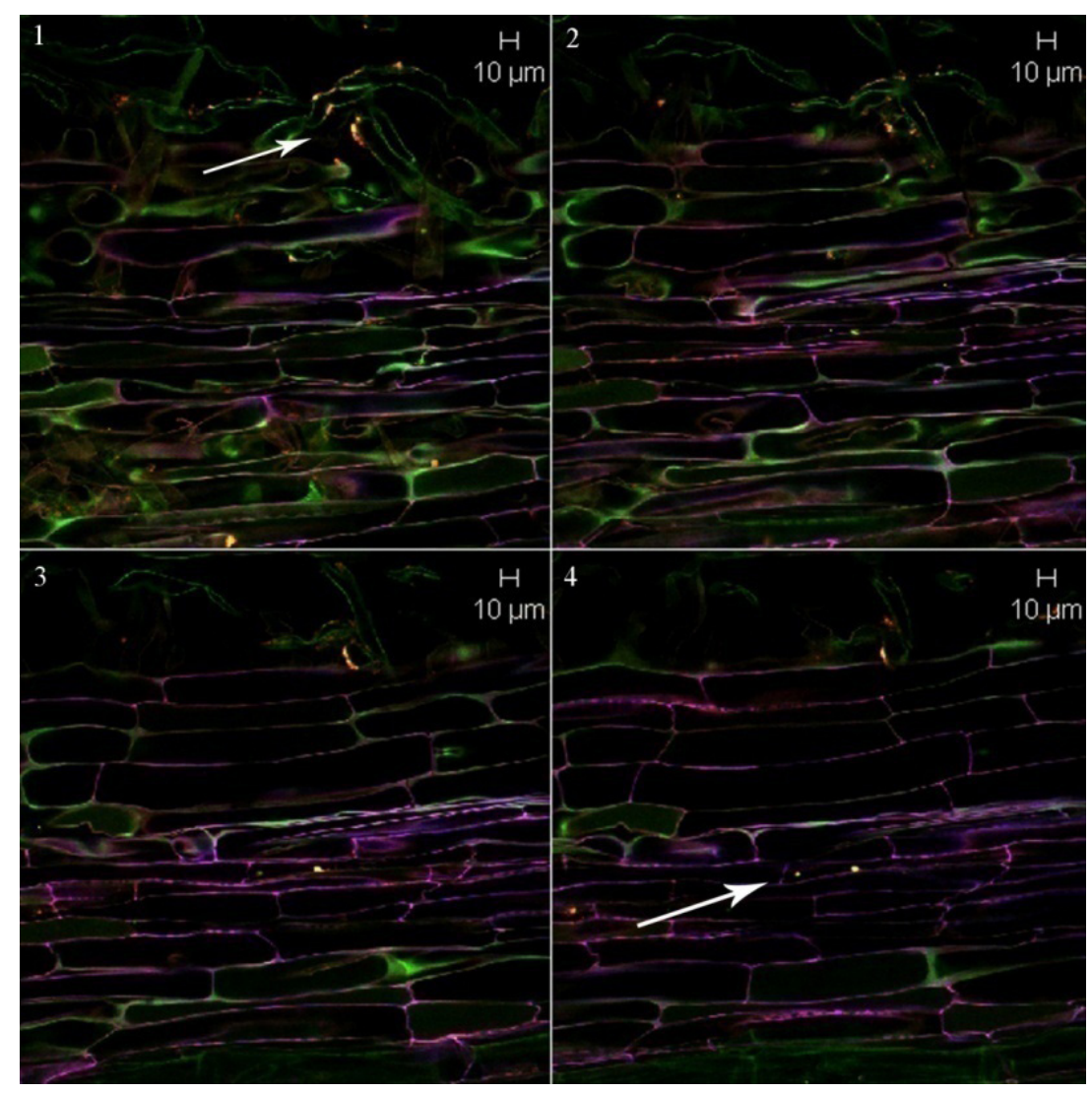

Figure 7: CLSM micrograph of endophyt colonization root by Salmonella typhimurium.

\section{Acknowledgement}

This study was supported by the EU Commission (FP7 project AREA) and Serbian Ministry of Education, Science and Technological Development (project TR 31080).

I am very thankful to Prof. Anton Hartmann, Dr Michael Schmid, Angelo Weiß and all people from Helmholtz Zentrum Munchen, Germany, AMP Research Unit Microbe-Plant Interactions who helped me to realize my research. 


\section{References}

Amann, R. I., Krumholz, L. \& Stahl, D. A. (1990). Fluorescent-oligonucleotide probing of whole cells for determinative, phylogenetic, and environmental studies in microbiology. Journal of Bacteriology 172, 762-770. DOI: https:// doi.org/10.1128/jb.172.2.762-770.1990

Amann, R.I., Zarda, B., Stahl, D. A. \& Schleifer, K. H. (1992). Identification of individual prokaryotic cells by using enzyme labeled, rRNA-targeted oligonucleotide probes. Apply Environtal Microbiology 58, 3007-3011.

Barak D. J., Whitehead L. C. \& Charkowski A. O. (2003). Difference in Attachment of Salmonella enterica Serovars and Escerichia coli O157:H7 to Alfalfa Sprouts. Apply Environtal Microbiology 69 (8),4556-4560. DOI: https://doi. org/10.1128/AEM.68.10.4758-4763.2002

Beuchat, L. R. (2002). Ecological factors influencing survival and growth of human pathogens on raw fruits and vegetables. Microbes and Infections 4, 413-423. DOI: https://doi.org/10.1016/S1286-4579(02)01555-1

Beuchat, L. R., \& Ryu, J. H. (1997). Produce handling and processing practices. Emerging Infectious Diseases. 3,459-465. DOI: https://doi.org/10.3201/ eid0304.970407

Brandl, M. T. \& Mandrell. R. E. (2002). Fitness of Salmonella enterica serovar Thompson in the cilantro phyllosphere. Apply Environtal Microbiology. 68, 3614-3621. DOI: https://doi.org/10.1128/AEM.68.7.3614-3621.2002

Burun B. \& Coban Poyrazoglu, E. (2002). Embryo Culture in Barley (Hordeum vulgare L.). Turkish Journal of Biology 26, 175-180.

CDC (2006). Ongoing multistate outbreak of Escherichia coli serotype O157:H7 infections associated with consumption of fresh spinach - United States, September 2006. Morb Mortal Wkly Rep 55, 1045-1046. https://www.cdc. gov/mmwr/preview/mmwrhtml/mm55d926a1.htm

Charkowski, A. Barak, O.J.D., Sarreal, C. Z. \& Mandrell, R. E. (2002). Differences in growth of Salmonella enterica and Escherichia coli Ol57:H7 on alfalfa sprouts. Apply Environtal Microbiology 68(6), 3114-3120. DOI: https://doi.org/10.1128/AEM.68.6.3114-3120.2002

Cooley, M. B., Miller, W. G. \& Mandrell, R. E. (2003). Colonization of Arabidopsis thaliana with Salmonella enterica or enterohemorrhagic Escherichia coli $\mathrm{Ol} 57: \mathrm{H} 7$ andcompetition by Enterobacter asburiae. Apply Environtal Microbiology 69, 4915-4926. DOI: https://doi.org/10.1128/AEM.69.8.49154926.2003.

Cummings, K., Barrett, E., Mohle-Boetani, J. C., Brooks, J. T., Farrar, J.T., Hunt, Fiore, A., Komatsu, K., Werner, S. B. \& Slutsker, L. (2001). A multistate outbreak of Salmonella enterica serotype baildon associated with domestic raw tomatoes. Emerging Infectious Diseases 7, 1046-1048. DOI: https://doi. org/10.3201/eid0706.010625 
Dong, Y, Iniguez, A. L. Ahmer, B. M. \& Triplett, E. W. (2003). Kinetics and strain specificity of rhizosphere and endophytic colonization by enteric bacteria on seedlings of Medicago sativa and Medicago truncatula. Apply Environtal Microbiology 69, 1783-1790, DOI: https://doi.org/10.1128/ AEM.69.3.1783-1790.2003

Doyle, M. P., \& Schoeni. J. L. (1986). Isolation of Campylobacter jejuni from retail mushrooms. Apply Environtal Microbiology 51, 449- 450.

Eldor, P. (2007). Soil Microbiology, Ecology and Biochemistry. Oxford: Academic Press is an imprint of Elsevier, ISBN: 9780123914118

Gandhi, M., Golding, S. Yaron, S. \& Matthews, K. R. (2001). Use of green fluorescent protein expressing Salmonella Stanley to investigate survival, spatial location, and control on alfalfa sprouts, Journal of food protection 64, 1891-1898. DOI: https://doi.org/10.4315/0362-028X-64.12.1891

Gillespie, I.A. (2004). Outbreak of Salmonella Newport infection associated with lettuce in the UK. Eurosurveillance Weekly 8, http://www.eurosurveillance.org/ViewArticle.aspx?ArticleId=2562

Guo, X. Chen, J., Brackett, R. E. \& Beuchat, L. R. (2001). Survival of salmonellae on and in tomato plants from the time of inoculation at flowering and early stages of fruit development through fruit ripening. Apply Environtal Microbiology 67, 4760-4764. DOI: https://doi.org/10.1128/AEM.67.10.47604764.2001

Guo, X., van Iersel, M. W., Chen, J., Brackett, R. E. \& Beuchat, L. R. (2002). Evidence of association of salmonellae with tomato plants grown hydroponically in inoculated nutrient solution. Apply Environtal Microbiology 68 (7), 3639-3643. DOI: https://doi.org/10.1128/AEM.68.7.3639-3643.2002

Hedberg, C. W., Angulo, F. J., White, K. E., Langkop, C. W., Schell, W. L., Stobierski, M. G., Schuchat, A., Besser, J. M., Dietrich, S., Helsel, L., Griffin, P. M., McFarland, J. W. \& Osterholm, M. T. (1999). Outbreak of salmonellosis associated with eating uncooked tomatoes: implications for public health. Epidemiology \& Infection 122, 385-393. DOI: https://doi.org/10.1017/ S0950268899002393

Horby, P.W., O’Brien, S.J., Adak, G.K., Graham, C., Hawker, J.I., Hunter, P., Lane, C., Lawson, A.J., Mitchell, R.T., Reacher, M.H., Threlfall, E.J. \& Ward, L.R. (2003). A national outbreak of multiresistant Salmonella enterica serovar Typhimurium definitive phage type (DT) 104 associated with consumption of lettuce. Epidemiology \& Infection 130, 169-178, DOI: https://doi. org/10.1017/S0950268802008063

Islam, M., Morgan, J., Doyle, M.P., Phatak, S.C., Millner, P. \& Jiang, X. (2004). Fate of Salmonella enterica serovars Typhimurium on carrots and radishes grown in fields treated with contaminated manure composts or irrigation water. Apply Environtal Microbiology 70, 2497-2502. DOI: https:/doi. org/10.1128/AEM.70.4.2497-2502.2004 
Jablasone, J., Warriner, K. \& Griffiths, M. (2005). Interactions of Escherichia coli O157:H7, Salmonella Typhimurium and Listeria monocytogenes in plants cultivated in a gnotobiotic system. Internatiol Journal of Food Microbiology 99, 7-18.

Jerngklinchan, J. \& Saitanu, K. (1993). The occurrence of salmonellae in bean sprouts in Thailand. The Southeast Asian Journal of Tropical Medicine and Public Health 24, 114-118.

Manz, W., Amann, R., Ludwig, W., Wagner, M. \& Schleifer, K.H. (1992). Phylogenetic oligodeoxynucleotide probes for the major subclasses of Proteobacteria: problems and solutions. Systematic and Applied Microbiology 15, 593-600. DOI: https://doi.org/10.1016/S0723-2020(11)80121-9

Moter, A., \& Gobel, U. (2000). Fluorescence in situ hibridization (FISH) for direct visualisation of microorganisms. Journal of Microbiological Methods 41(2), 85-112. DOI: https://doi.org/10.1016/S0167-7012(00)00152-4

Natvig, E.E., Ingham, S.C., Ingham, B.H., Cooperband, L.R. \& Roper, T.R. (2002). Salmonella enterica serovar Typhimurium and Escherichia coli contamination of root and leaf vegetables grown in soils with incorporated bovine manure. Apply Environtal Microbiology 68, 2737-2744. DOI: https:// doi.org/10.1128/AEM.68.6.2737-2744.2002

Pezzoli, L., Elson, R., Little, C., Fisher, I., Yip, H., Peters, T., Hampton, M., De Pinna, E., Coia, J.E., Mather, H.A., Brown, D.J., Nielsen, E.M., Ethelberg, S., Heck, M., de Jager, C. \& Threlfall, J. (2007). International outbreak of Salmonella Senftenberg in 2007. Eurosurveillance Weekly 12, (accessed on 15/ 06/07) http://www.eurosurveillance.org/ViewArticle.aspx? ArticleId=3218

Raina M. Maier, Ian L. Pepper, Charles P. Gerba., Blomme, B., \& Handler, A. (2009). Enviromental Microbiology 2nd ed. Amsterdam; Boston: Elsevier/ Academic Press, c2009 9780123705198

Smit, G., Kijne, J. W. \& Lugtenberg, B. J. (1987). Involvement of both cellulose fibrils and a Ca2+-dependent adhesin in the attachment of Rhizobium leguminosarum to pea root hair tips. Journal of Bacteriology 169(9), 4294-4301. DOI: https://doi.org/10.1128/jb.169.9.4294-4301.1987

Soderstrom, A., Lindberg, A. \& Andersson, Y. (2005). EHEC O157 outbreak in Sweden from locally produced lettuce, August-September 2005. Eurosurveillance, 10 (9): E050922.1 Retrieved from (http://www.eurosurveillance. org/ViewArticle.aspx?ArticleId=2794).

Takkinen, J., Nakari, U-M., Johansson, T., Niskanen, T., Siitonen, A. \& Kuusi, M. (2005). A nationwide outbreak of multiresistant Salmonella Typhimurium var. Copenhagen DT104B infection in Finland due to contaminated lettuce from Spain, May 2005. Eurosurveillance Weekly 10(26). Retrieved from http://www.eurosurveillance.org/ViewArticle.aspx?ArticleId=2734

Viswanathan, P. \& Kaur, R. (2001). Prevalence and growth of pathogens on salad vegetables, fruit and sprouts. International Journal of Hygiene and Environtal Health 203, 205-213. DOI: https://doi.org/10.1078/S14384639(04)70030-9 
Warriner, K., Spahiolas, S., Dickinson, M., Wright, C. \& Waites. W. M. (2003). Internalization of bioluminescent Escherichia coli and Salmonella Montevideo in growing bean sprouts. Journal Apply Microbiology 95, 719-727. DOI: https://doi.org/10.1046/j.1365-2672.2003.02037.x

Zogaj, X., Nimtz, M., Rohde, M., Bokranz, W. \& Romling. U. (2001). The multicellular morphotypes of Salmonella Typhimurium and Escherichia coli produce cellulose as the second component of the extracellular matrix. Molecular Microbiology 39, 1452-1463. DOI: https://doi.org/10.1046/ j.1365-2958.2001.02337.x 
